\title{
Seasonal Variation in Leaf Mineral Nutrient and Optimization of Sampling Dates for Better Indexing of Pear Leaf
}

\author{
A. Raouf Malik ${ }^{1 *}$, M. Feza Ahmad ${ }^{2}$, M. A. Ganie ${ }^{1}$, S.A. Bangroo ${ }^{1}$, Nawsheen Nazir ${ }^{1}$, \\ Aroosa Khalil ${ }^{1}$ and R.H.S. Raja ${ }^{3}$
}

\begin{abstract}
Sher-e-Kashmir University of Agricultural Sciences and Technology of Kashmir, Shalimar, Srinagar, Jammu and Kashmir 191 121, India ${ }^{2}$ Bihar Agricultural University Sobour Baghalpur 813210, India

${ }^{3}$ Central Institute of Temperate Horticulture Srinagar $J \& K$, India
\end{abstract}

*Corresponding author

\section{A B S T R A C T}

\begin{tabular}{|l|}
\hline Key w o r d s \\
Pear, seasonal \\
variation, Leaf \\
index tissue, \\
Sampling Date, \\
Nutrient \\
\hline Article Info \\
\hline $\begin{array}{l}\text { Accepted: } \\
\text { 10 January } 2019 \\
\text { Available Online: } \\
\text { 10 February } 2019\end{array}$ \\
\hline
\end{tabular}

\section{Introduction}

Pear (Pyrus communis L) is one of the most important fruit crops of the world in India pear is being mostly produced in $J \& K$ and Himachal Pradesh, Foliar analysis has been widely accepted as a valuable guide to determine the fertility status in fruit plants. Composition of nutrient in the leaf after six months of planting indirectly reflects on the growth, development and yield (Kumbargiri et al., 2016).
The present investigation aimed at evaluating the seasonality of macro-nutrients contents of pear trees during the agriculture year 2007. Therefore, leaf samples were collected at fortnightly intervals form $1^{\text {st }}$ may to $1^{\text {st }}$ October and evaluated for nutrients. In general concentration of $\mathrm{N}, \mathrm{P}, \mathrm{K}$ decreased and those of $\mathrm{Ca}, \mathrm{Mg}, \mathrm{Fe}$, and $\mathrm{Mn}$ content increased from first to last sampling date while as no conspicuous trend was observed in $\mathrm{Cu}$ content of leaves. The distinct period of stability for $\mathrm{N}, \mathrm{Mg}, \mathrm{Mn}$ and $\mathrm{Zn}$ contents occurred from July 15- August 15 . However, P content of leaves showed least variation from July 1 to august 1 . While stability period for leaf $\mathrm{Ca}$ was recorded from August 1 to September 1 . While $\mathrm{Cu}$ and B were found to be stable from June 1-July 15. It is as such suggested that the leaves should be sampled form middle portion of current season growth from periphery during most stable periods of a particular nutrient for its proper diagnosis. However in general, July to August is the most representative period for diagnosis of leaf nutrient content in the leaves.

Considerable work done on various fruit crops suggest that best time for collecting leaf samples is a relative stable period of a few weeks or months when mineral shifts are at minimum (Mason,1958). Several factors, namely, leaf age, position, climate, cultivar season etc, influenced nutrient concentration in leaf (Robinson, 1981). Although, J \& K is one of the important pear producing states in India, yet a standard sampling time has not been developed for the leaf analysis. Thus being a commercially important fruit crop of $\mathbf{J}$ 
\& $\mathrm{K}$, it was considered necessary to standardize the optimum leaf sampling date for pear which will provide correct information about the nutritional status of species growing in a particular locality and in formulating fertilizer schedule.

\section{Materials and Methods}

The experiment was conducted at the experimental orchard of the Division of Pomology, SKUAST-K, Shalimar Srinagar (J\&K) during the year 2007-2008. Eight wellspaced healthy trees of pear cv. Bartlet and cv. Chinese sandy pear of uniform age, vigour and productivity were selected. Leaf samples were collected from middle portion of the current seasons growth from $1^{\text {st }}$ May to $1^{\text {st }}$ October at fortnightly intervals. The leaf samples were thoroughly washed first with tap water, then dipped in $0.1 \mathrm{NHCl}$, distilled water and finally in double distilled water. After air drying, the samples were dried in oven at $58^{\circ} \mathrm{C}$ till it attained constant weight. The dried leaves were ground in steel willey mill. Nitrogen was determined by micro Kjeldhel method while phosphorus was determined by Vanadomolybedo phosphoric acid yellow colour method (Jackson, 1967). Potassium and Calcium were estimated by flame photometer. However, magnesium and micronutrients were analyzed by atomic absorption method using atomic absorption spectrophotometer (ECIL 4141). However, boron was analyzed through calorimeter.

\section{Results and Discussion}

The data presented in table 1 clearly indicate that $\mathrm{P}, \mathrm{K}, \mathrm{Ca}$ and $\mathrm{Mg}$ contents were higher in the leaves sampled from Chinese Sandy pear while as leaf $\mathrm{N}$ content was found to be higher in Bartlett leaves. The data related to $\mathrm{N}, \mathrm{P}$ and $\mathrm{K}$ content of pear leaves influenced by sampling dates is presented in figure 4-6 respectively. Leaf $\mathrm{N}$ content decreased from 1.903 to 0.368 per cent from May 1 to
October (Fig. 4). While as $\mathrm{P}$ and $\mathrm{K}$ content (Fig. 5 and 6) decreased from 0.350 per cent to 0.136 per cent and 1.006 percent to 0.406 percent respectively from first sampling date (May 1) to last sampling date (October 1). The decreasing trend of N, P and K content of pear leaves observed in present investigation is associated with the growth dilution effect (Smith, 1962). And also might be due to utilization of these nutrients by various sinks at different stages of development. The decrease in $\mathrm{N}$ content during growing season is in conformity to report of various workers for both evergreen and deciduous fruit trees (Koo and Young 1977 and Brown 1994). The decrease in $\mathrm{P}$ and $\mathrm{K}$ content with the advancement of growing season is also confirmed by the findings of Kamboj et al., (1987), Chandel and Rana (2004) in Kiwi and Ragini et al., (2015) in litchi. However the stability period with respect to $\mathrm{N}, \mathrm{P}$ and $\mathrm{K}$ content of pear leaves was recorded from July 15, August 15, June 15 to July 15 and July 1 to August 1 respectively. Kamboj et al., (1987) reported distinct period of stability in Patharnakh for N, P and K contents from July to September. The variation in the stability periods observed in the present findings might be due to different agro-climatic conditions. In contrast to primary nutrients, $\mathrm{Ca}$ and $\mathrm{Mg}$ contents (Fig. 7 and 8) of leaves increased with the advancement of leaf age. However a decrease in leaf $\mathrm{Mg}$ content of pear was recorded from September 15 onwards. The increasing trend of $\mathrm{Ca}$ and $\mathrm{Mg}$ content of leaves with age may be attributed to their limited mobility in phloem (Smith, 1962). While as the decrease in $\mathrm{Mg}$ content after September 1 may be due to remobilization of this element in the plant system. The lowest $\mathrm{Ca}$ and $\mathrm{Mg}$ (Fig. 7 and 8) was recorded on first date of sampling i.e. on May $1(0.762 \%$ $\mathrm{Ca}$ and $0.527 \% \mathrm{Mg}$ ). However, the maximum level of $\mathrm{Ca}$ was recorded on October -1 (2.821\%) while as that of $\mathrm{Mg}$ was observed on September-1 $(0.734 \%)$. The results of the 
present findings are in relation to the results of Kamboj et al., (1987) and Rehalia and Sandhu (2005) who also reported an increase in $\mathrm{Ca}$ and $\mathrm{Mg}$ content with the advancement of leaf age of pear leaves and in persimmon, leaves respectively. In contrary Buwalda and Meekings (1990) observed that the concentration of $\mathrm{Mg}$ in spur leaves of pear declined with the advancement of growing season. The present investigation also revealed that most nutrient stability period (which is the most ideal leaf sampling date) in pear leaves for $\mathrm{Ca}$ and $\mathrm{Mg}$ was July 1 August 15 and July 15 - August 15 respectively.

As far as micronutrients are concerned, Mn, $\mathrm{Zn}$ and $\mathrm{B}$ were recorded higher in Chinese sandy pear than that of Bartlet leaves (Table 1). While as $\mathrm{Cu}$ was found to be higher in $\mathrm{cv}$. Bartlet, however, a non significant difference was recorded in Fe content of two cultivars. The studies on periodical variation of $\mathrm{Mn}$ and Fe (Fig. 6 and 7) exhibited an increasing trend as the season advanced, till September 1, thereafter, a decreasing trend was recorded till last date of sampling. The maximum content of $\mathrm{Mn}$ and $\mathrm{Fe}$ was recorded on September 1 (84.59 ppm and $177.36 \mathrm{ppm}$, respectively) (Fig. 6 and 7). While as minimum leaf Mn and Fe was recorded on May 1 (42.94 ppm and $117.34 \mathrm{ppm}$, respectively). Further Mn and $\mathrm{Fe}$ content of Pear leaf attained least variation during July 15 to August 15 and July 1 to August 1 respectively. The increment in leaf nutrient content with leaf age may be attributed to their fewer requirements by the fruits as compared to other elements (Raghupatri and Bhargava, 1996).

Copper content of pear leaves did not followed a definite trend and a highest $\mathrm{Cu}$ content was observed on first sampling date i.e. on May $1(21.79 \mathrm{ppm})$ and after that decreased gradually till June 15 (Fig. 8), thereafter increased on July 1 and thereafter again decreased towards the close of sampling season. Copper content of leaves from June 1 to July 15 appeared to be stable. The trend observed in the present investigation may be due to relatively partial mobility of the element in the plant system. Rossi (1970) observed that in apple and pear leaf copper content increased up to May and then decreased with advancement of sampling period till September.

The leaf $\mathrm{Zn}$ content (Fig. 9) of leaves increased from the first date of sampling i.e. May 1 to June 1 . Then decreased afterwards to reach its minimum on October 1 . While as boron concentration (Fig. 10) of leaves showed a general decrease throughout the season.

Table.1 Varietal effect of pear on leaf macro and micro-nutrient content

\begin{tabular}{|c|c|c|c|c|c|c|c|c|c|c|}
\hline \multirow[t]{2}{*}{ Varieties } & \multicolumn{3}{|c|}{ Primary Nutrient } & \multicolumn{2}{|c|}{$\begin{array}{l}\text { Secondary } \\
\text { Nutrient }\end{array}$} & \multicolumn{5}{|c|}{ Micro-nutrient } \\
\hline & $\begin{array}{l}\text { Nitrogen } \\
(\%)\end{array}$ & $\begin{array}{l}\text { Phosphorus } \\
(\%)\end{array}$ & $\begin{array}{l}\text { Potassium } \\
(\%)\end{array}$ & $\begin{array}{l}\text { Calcium } \\
(\%)\end{array}$ & $\begin{array}{l}\text { Magnesium } \\
(\%)\end{array}$ & $\begin{array}{l}\text { Manganese } \\
(\mathrm{ppm})\end{array}$ & $\begin{array}{l}\text { Iron } \\
(\mathbf{p p m})\end{array}$ & $\begin{array}{l}\text { Copper } \\
\text { (ppm) }\end{array}$ & $\begin{array}{l}\text { Zinc } \\
(\mathbf{p p m})\end{array}$ & $\begin{array}{l}\text { Boron } \\
(\mathbf{p p m})\end{array}$ \\
\hline $\begin{array}{l}\text { Chinese } \\
\text { Sandy Pear }\end{array}$ & 1.202 & 0.183 & 0.751 & 2.167 & 0.680 & 70.61 & 158.40 & 16.02 & 31.00 & 41.36 \\
\hline Bartlett & 1.580 & 0.168 & 0.441 & 1.703 & 0.663 & 57.89 & 155.51 & 21.50 & 24090 & 36.8 \\
\hline $\begin{array}{l}\text { CD } \\
(P<0.05)\end{array}$ & 0.040 & 0.006 & 0.046 & 0.029 & NS & 3.33 & NS & 1.21 & 0.92 & 1.24 \\
\hline
\end{tabular}


Int.J.Curr.Microbiol.App.Sci (2019) 8(2): 1152-1157
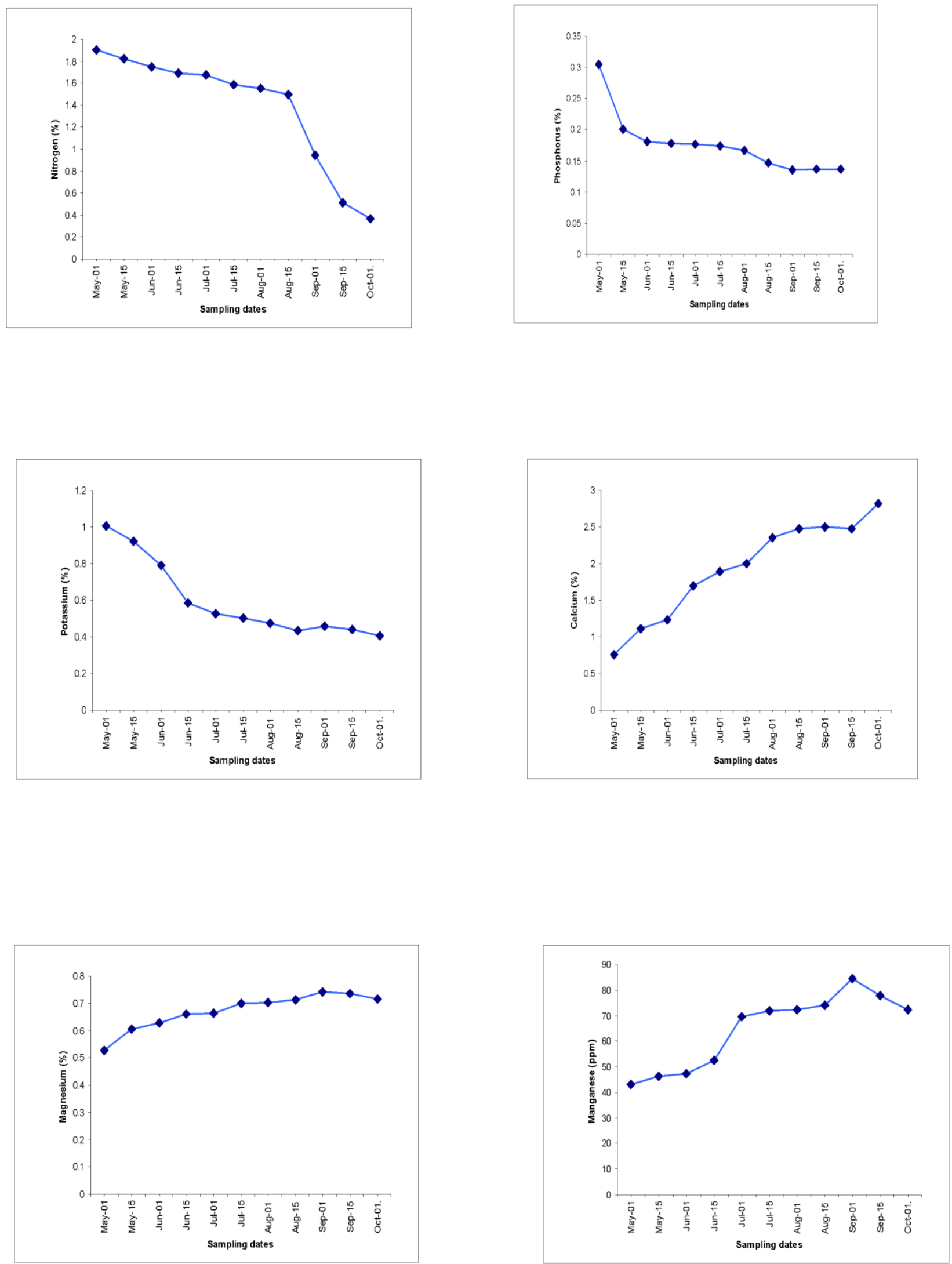

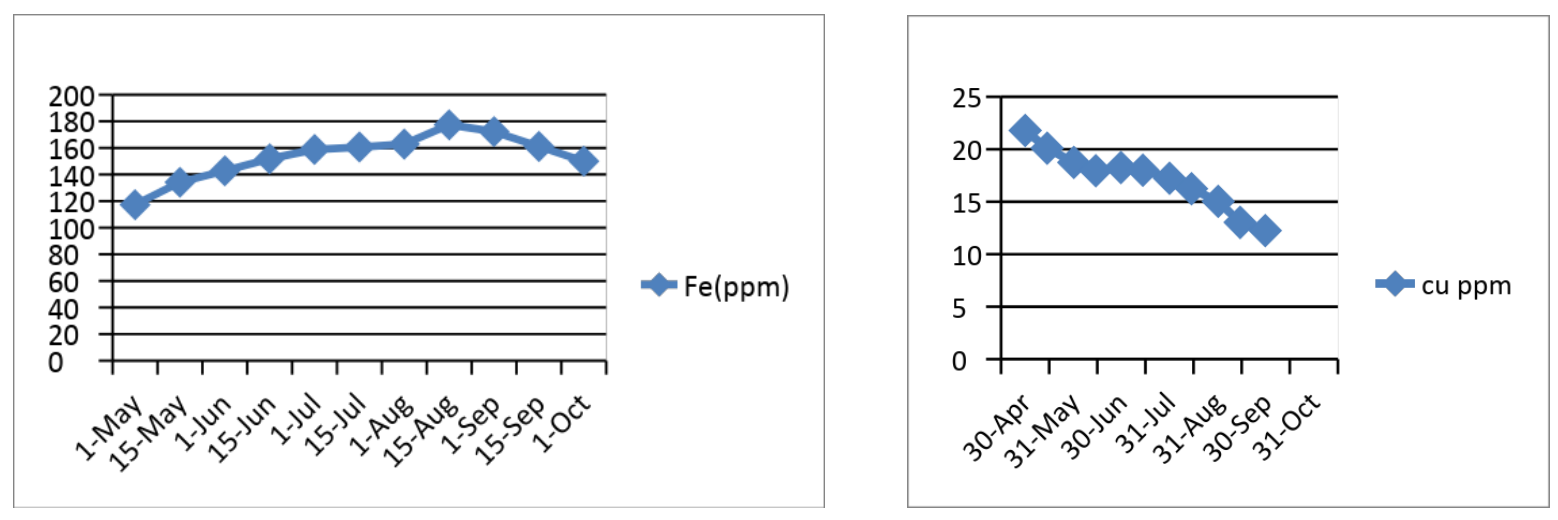

The maximum B was recorded on May 1 (48.15 ppm) and minimum on October 1 (25.90 ppm). However, least variation in $\mathrm{Zn}$ and B content of pear leaves was recorded during July 15 to August 15 and June 15 to July 15 respectively. The maximum level of $\mathrm{Zn}$ content on earlier sampling dates may be due to the fact that period of greater accumulation of $\mathrm{Zn}$ occurs between leaf emergence and fruit set (Smith et al., 1987) while as the depletion in leaf B around anthesis may be linked to B mobilization from the leaves to supply B requirement of flowers and fruits (Delgado et al., 1994).

The periodical variation on leaf nutrient concentration in pear indicate that in general nitrogen, phosphorus, potassium, zinc and boron decreased with the advancement of leaf sampling period while as calcium, magnesium, manganese, and iron increased with the leaf age. However, copper content of the leaves from pear did not show any regular trend. Further, it is often difficult to select a sampling date which is suitable for all nutrients because of difference in their seasonal trends (Cresswell and Wickson, 1986). One compromise is to choose a sampling date when the concentration of most nutrients is more stable. From Figure 1-10 it can be seen that most of the nutrients show least variation from July to August. Thus July to August can be regarded as the optimal sampling date for diagnosis of nutrient status of pear tree. It is as such suggested that the pear leaves should be sampled from middle portion of current seasons growth from periphery during July to August for simultaneous analysis of nutrients. However for a particular nutrient diagnosis, the leaves should be sampled from the current season growth during the stability period for that particular nutrient.

\section{References}

Brown P H. 1994. Seasonal variation in fig (Gicus carica L.) leaf nutrient concentrations. Horticultural Sciences 29(8): 871-873.

Buwalda J G and Meekings J S. 1990. Seasonal accumulation of mineral nutrient in leaves and fruit of Japanese pear (Prunus serotina Rehd.). Scientia Horticulture 41: 209-222.

Chandel, J.S. and Rana, R. K.(2004). Standardization of leaf sampling techniques for kiwi fruit in mid hill conditions of Himachal Pradesh. Haryana J Hortl Sci., 33 (1\&2):30-33.

Cresswell G C and Wickson R J. 1986. Seasonal variation in the nutrient composition of the foliage of pecan. Aust. J. Exp. Agri. 26: 393-397.

Delgado A, Benlloch M and Fernandez E R. 1994. Mobilization of boron in olive trees during flowering and fruit development. Hort. Sci. 29: 616-618. 
Jackson M L. 1967. Soil chemical analysis, Asia Publishing House, Bombay.

Kamboj J S, Datt A S and Rehalia A S. 1987. Standardization of leaf sampling technique in subtropical pear. Punjab Hor. J. 27 (3-4): 121-132.

Koo R C J and Young T W. 1977. Effects of age, position and fruiting status on mineral composition of 'Tonnage' avocado leaves. J. Amer. Soc. Hort. Sci. 102: 311-313.

Kumbargire, G. A. Swamy, G. S. K. and Kalatippi, A. S. 2016. Influence of diatomaceous earth as source of silicon on leaf nutrient status and yield attributing characters of banana cv. Grand Naine. The Bioscan 11(1): 435438 ,

Mason A C. 1958. The concentration of certain nutrient elements in apple leaves taken from different positions on shoot and at different dates throughout the growing season. J. of Hort. Sci. 33: 128138.

Raghupathi H B and Bhargava B S. 1998. Leaf and soil nutrient diagnosis norms for pomegranate (Punica granatum L.). J. of the Indian Soci. of Soil Scien. 46
(3): 412-416.

Ragini, K. Prabhakar, M. Kumari, N. Rajeev, K. and Rajendra P. S. 2015. Temporal and axial variation for primary nutrient concentration in leaves of litchi. The Bioscan. 10(3): 1145-1148.

Rehalia, A.S.and Sandhu, R.D. 2005. Standardization of foliar sampling technique for micronutrients in persimmon (Diospyrous Kaki L.). Acta Hortic., 696:265-268

Robinson A D. 1981. Principles and approaches used in plant analysis. Proceedings of National Workshop Plant Analysis Report, 34-37.

Rossi N. 1970. The macro and micro nutrient contents of the leaves some of apple and pear in orchard in Emila, Cent. Edafol. Bio. Aplic. Curato. Sevilea, Spain 607615.

Smith G S, Clark C J and Henderson H V. 1987. Seasonal accumulation of mineral nutrients by kiwifruit. New Phytol 106 (1): 81-100.

Smith P F. 1962. Mineral analysis of plant tissues. Ann. Rev. of Plant Physiol. 13: 81-108.

\section{How to cite this article:}

Raouf Malik, A., M. Feza Ahmad, M.A. Ganie, S.A. Bangroo, Nawsheen Nazir, Aroosa Khalil and Raja, R.H.S. 2019. Seasonal Variation in Leaf Mineral Nutrient and Optimization of Sampling Dates for Better Indexing of Pear Leaf. Int.J.Curr.Microbiol.App.Sci. 8(02): 11521157. doi: https://doi.org/10.20546/ijcmas.2019.802.134 